\title{
Myopericytoma as a Differential Diagnosis of Pyogenic Granuloma
}

\author{
Camila Scharf ${ }^{1}$, Giuseppe Argenziano ${ }^{1}$
}

1 Dermatology Unit, University of Campania Luigi Vanvitelli, Naples, Italy

Key words: myopericytoma, pyogenic granuloma, dermoscopy, soft-tissue tumor, myofibroma

Citation: Scharf C, Argenziano G. Myopericytoma as a differential diagnosis of pyogenic granuloma. Dermatol Pract Concept. 2021;11(1):e2021105. DOI: https://doi.org/10.5826/dpc.1101a105

Accepted: June 24, 2020; Published: January 29, 2021

Copyright: $\odot 2021$ Scharf and Argenziano. This is an open-access article distributed under the terms of the Creative Commons Attribution License BY-NC-4.0, which permits unrestricted noncommercial use, distribution, and reproduction in any medium, provided the original author and source are credited.

Funding: None.

Competing interests: The authors have no conflicts of interest to disclose.

Authorship: Both authors have contributed significantly to this publication.

Corresponding author: Camila Scharf, MD, MSc, Via Sergio Pasini, 5, 80131 Naples, Italy. Email: camila.scharf@unicampania.it

\section{Case Presentation}

A 46-year-old male first visited the dermatology unit complaining of a fast-growing lesion on the ankle (Figure 1A). Dermoscopy initially revealed typical findings pointing to pyogenic granuloma with homogeneous white-red areas surrounded by a whitish collarette (Figure 1B). Since the lesion
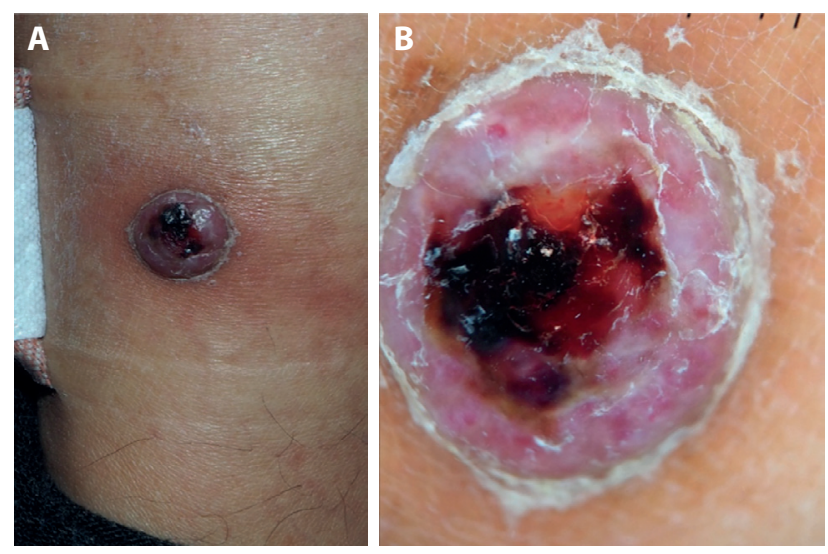

Figure 1. (A) Well-defined lesion, clinically consistent with pyogenic granuloma. (B) Dermoscopy showing homogeneous white-red areas surrounded by a whitish collarette. was painful and friable, it was excised, and histopathology reported a myopericytoma.

\section{Teaching Point}

Myopericytoma is a rare, benign, slow-growing soft-tissue tumor of perivascular cells. The most common location is on the distal extremities, and though the etiology is unknown, it has been associated with local trauma. Histologically, it is characterized by a well-circumscribed, nonencapsulated proliferation of spindle-shaped cells arranged in perivascular concentric rings. Therefore, it can be a differential diagnosis for hemangiopericytomas, myofibromas, and glomus tumors. Dermoscopy has been previously disclosed unfocused arborizing vessels, structureless light brown areas, and shiny white streaks $[1,2]$. In our case, dermoscopy presented homogeneous white-red areas surrounded by a whitish collarette and classic features of pyogenic granuloma, which was our first clinical suspicion. Dermoscopy training is essential for all practitioners and with experience we might banalize a few cases, but we must keep in mind that some dermoscopic features may be shared by different lesions. 


\section{References}

1. Boix-Vilanova J, del Pozo Hernando LJ, Rodrigo Lara H, Corral-Magaña O. [Distal digital myopericytoma: a dermoscopy case study]. Actas Dermosifiliogr. 2020;111(4):338-341. DOI: 10.1016/j.ad.2018.09.015. PMID: 31627853.
2. Ruiz-Arriaga LF, Ramirez Teran AL, Ortiz-Hidalgo C, et al. Myopericytoma in an unusual location. Dermatol Online J. 2018;24(4):13030/qt5z02t0dk. PMID: 29906007. 